\title{
Creative
}

\section{On the Slab, Our Architecture under Construction}

\author{
Ligia Nobre $^{1, *}$ and Anderson Kazuo Nakano ${ }^{2}$ \\ 1 Architecture and Urbanism, Escola da Cidade, São Paulo 01223-011, Brazil \\ 2 Architecture and Urbansim Course, Centro Universitário Belas Artes de São Paulo, São Paulo 04018-010, \\ Brazil; kazuo.nakano@gmail.com \\ * Correspondence: ligiavnobreme@gmail.com
}

Received: 19 July 2017; Accepted: 7 August 2017; Published: 17 August 2017

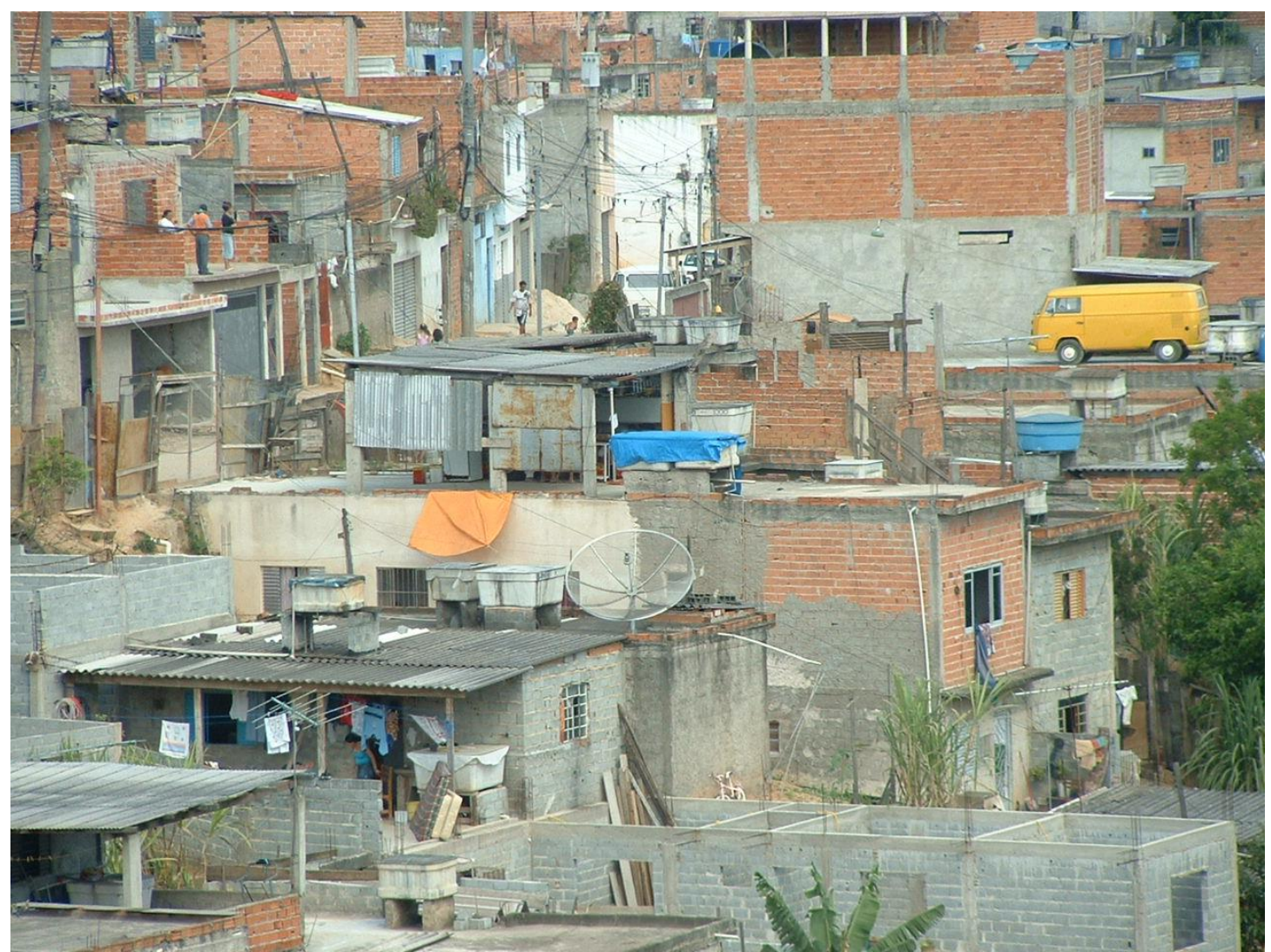

On the slab, São Paulo, 2003. Photo by Ligia Nobre.

\section{São Paulo S.A. ${ }^{1}$}

The 1950s and 60s was marked by the developmentalism, industrialization, and modernization of the peripheral capitalism of Brazil and by the demographic explosion and unprecedented urban expansion in the country. Throughout these decades, São Paulo became the political, cultural, and economic epicenter of Brazil, as well as an example of the worldwide phenomenon of great metropolises. The city's territories are marked by inequalities between the low- and high-income groups, each with distinct access to urban spaces, resources, and public infrastructure. However,

1 In Portuguese-s.a. is sociedade anônima; In English it means anonymous society. 
the borders are tenuous and porous between the so-called 'global city' and the places of the 'excluded' and 'poor people'. In the 1970s and 80s, the social and political movements occurring in São Paulo contributed to the long process of the "re-democratization" of Brazilian society. In a long-lasting regime- built at the intersection between legal and illegal, public and private-the social urban movements played an essential role in the creation of a new conception of "urban citizenship" (Caldeira and Holston 2004).

In the last two decades, the peripheries have changed a lot; they no longer correspond to the images of rarefied occupation and desolation of 40 years ago. There are completely new territorial configurations with large private investments, such as supermarkets and shopping malls, as well as public facilities, such as hospitals and state schools. In the clash between ownership, rented and illegal occupancy, the violence of the land conflicts erupts in the extremities of the city (Telles and Cabanes 2006). In the "acting out urbanizations" of the peripheries of the southern or eastern areas, the types of dwellings and their location in the urban fabric-with varied mobilities and access-imply completely distinct possibilities and outcomes of life for their inhabitants.

\section{The Concrete Slab}

The concrete slab is the common denominator within the territorializing patterns of popular "autoconstruction" dwellings-the clandestine settlement, the urban land occupation, or the slums in their final consolidated stages. The slab as a constructive component is used as a roof for constructions, which also generate small plateaus of an artificial topography used in various ways. The production of the slab is intrinsic to the mode of production of the informal city: starting with the irregular access to urban land, and influenced by a peculiar way of building houses, gradually and adjusted to the topographic profile, according to the variations of life trajectories, family cycles and the establishment of social micro-territories.

Although the land occupations and slum quarters bear manifold similarities to those of clandestine settlements, the procedures and strategies of access to the land are quite distinct from one another. Clandestine settlements have been the main alternative access to land for the low-income population in the peripheries of the metropolis of São Paulo, among other large Brazilian and Latin American cities. The informal processes of production of urban lands for "autoconstruction" dwellings define territories with intense use and occupation as well as higher and higher buildings and demographic densities. The gradual construction of a house is carried out by the inhabitants themselves, with the help of friends, neighbors, relatives, and informally hired bricklayers. Henceforth, the slabs' construction and uses follow life cycles, as areas for verandas, additions for new rooms, and places for collective sharing, interconnect domestic and urban dimensions.

A concrete slab construction represents family achievement, that demands many years of work and financial investment. As a political and household dispositif, the slab is also a "sign of what's yet to come". It serves as a support for expansions that might shelter families of newlyweds, children, or relatives from out-of-town. It might even be sold or rented, emerging as a source of income for its owners. All these activities take place in the peripheries of the metropolis, and have given rise to increasingly denser housing and population patterns, which in turn generate other cycles of urban informality. The evidence of this process is visible in the emergence of multiple-story houses.

\section{Micro-Territories}

In the house, the slab is composed of simple constructive systems. In general, it is covered with roof tiles, supported by small beams of concrete, and its permanent features comprise water reservoirs, asbestos roofing tiles, satellite dish aerials, and clotheslines with drying clothes, among others things. Access to the slab is generally through narrow ladders, 'controlled' or not by their respective house dwellers. Its multiple uses include sociability, hospitalities, reciprocal help, and exchanges of experiences and of information; acquaintanceship. 
The slab's usefulness reaches its peak on weekends. On these occasions, the slab turns into the place for family gatherings, visiting neighbors and friends, and for the famous barbecue served with lots of beer. It substitutes the old backyards eliminated by the increase in density of these very settlements. The slabs are also represented in the samba, rap, and hip hop. On the slab, people listen to music and play dominos, cards, and even soccer. They celebrate birthdays and marriages, or on New Year's Eve watch the fireworks. Children fly kites, dogs play around, women chat, adolescents date. Active and passive contacts are established, encompassing looks, smells, sounds, and bodies. In these houses with few and narrow openings, the slabs are "large open areas", offering not only a view of the horizon but also room for urban negotiations. The slab is also omnipresent in the collective imaginary, appearing in samba, funk, and in rap lyrics of the hip hop movement, as well as in everyday language; in daily life.

In the extreme case of drug trafficking, these concrete slabs with a privileged, broad view of the territory are occupied, establishing an almost absolute surveillance regime on the streets as well as a definition of closed territories. In this case, negotiations are shortened by authoritarian impositions which draw other diagrams of power relations. From a "surface of sociability" to a "surface of control and watch", the slabs place themselves as architectural "quasi-objects" engaged in the complex tangle of economic, legal, cultural, and environmental relations in the metropolis.

\section{On the Slab}

The slabs, with their multiple dimensions and ambivalences, pose us questions such as: Which architectures and societies do we want to build for ourselves? Which "signs of what is yet to come" do we want to activate in our daily practices towards the future? The slabs configure open fields with infinite possibilities for shared narratives in the unfinished condition of these landscapes. The heterogeneity which they host is both generative and destructive of social fabrics. Herein lies the potential (and responsibility) for fostering creative narratives, that coalesce on the wider slab that is the metropolis. ${ }^{2}$

Conflicts of Interest: The authors declare no conflict of interest.

\section{References}

Caldeira, Mieke, and James Holston. 2004. Estado e espaço urbano no Brasil: do planejamento modernista às intervenções democráticas. In Avritzer, Leonardo (org.) A participação em São Paulo. São Paulo: Universidade Estadual Paulista.

Telles, Vera da Silva, and Robert Cabanes. 2006. Nas tramas da cidade: trajetórias urbanas e seus territórios. São Paulo: Associação Editorial Humanitas.

(C) 2017 by the authors. Licensee MDPI, Basel, Switzerland. This article is an open access article distributed under the terms and conditions of the Creative Commons Attribution (CC BY) license (http://creativecommons.org/licenses/by/4.0/).

2 A larger version of this text was originally published in Livro para Ler, 10 anos de Capacete, by Editora Associação Capacete Ltda., Rio de Janeiro, 2008. Translation (Portuguese-English): Marcus Sodré. 